Hilan Bensusan

Universidade de Brasília

\title{
Observações sobre a política dos desejos: tentando pensar a o largo dos instintos compulsórios
}

\begin{abstract}
Resumo: O texto procura articular uma maneira feminista e holista de pensar a relação entre natureza e desejos. Tento considerar nossos desejos em relação a o nosso corpo e a como ele responde às forças nas nossas subjetividades, às pessoas a nossa volta e à história da nossa espécie. Começo considerando a distinção entre o político e o pessoal e daí faço algumas observações sobre a natureza e as três ecologias imbric adas uma na outra como dia gnostic ou Guattari. Proponho que entenda moso corpo como a confluência dessas ecologias e, a o mesmo tempo, como sendo ele mesmo nossa pla ta forma política. Proponho, então, um modelo acerca de como a natureza molda e restringe nossos desejos de um modo que nã o nos impõe nenhuma mensagem específica. Reflito, assim, sobre nossos instintos e como eles se insc revem na polític a de nossa espécie - e como eles podem ser transformados, uma vez que não são mais naturais que os dema is itens da nossa pa isa gem subjetiva. Essa transforma ção, eu argumento, deve ser pensada em termos de uma politização ecológica.
\end{abstract}

Palavras-chave: corpo; desejo; politiza ção; pornog ra fia; instintos; masculinida des.

Copyright a 2006 by Revista Estudos Feministas.

${ }^{1}$ BENSUSAN, 2004a.
0. O intuito central destas observações é esboçar um modelo para pensarmos nos desejos, nas relações políticas em tomo deles e na sua autonomia. O modelo é uma maneira de entender instintos e sua relação com o conteúdo de nossos desejos de uma maneira holista e compatível com muitos dos desidera ta feministas. Trata-se de um modelo em grande medida compatível com as observações sobre meus desejos e suas relações com outras pessoas e com meu treinamento sexual em Observações sobre a libido colonizada. ${ }^{1}$ Penso nesse modelo desde meu esforço por pensar minha situa ção de homem em uma socieda de patria rcal e, assim, ele emerge de minha maneira de lidar com os feminismos. Estas observações refletem esse caráter situa do da elaboração do modelo: nelas incluo algumas de minhas experiências 
hesita ntes a o tentar interferir no a pelo dos desejos que são associados comumente a instintos e apresento algumas inquieta ções a cerca do modo como os feminismos a tua m sobre a esfera dosmeus desejos. Os desejos são, de a lguma maneira, inculcados em nós no convívio com outras pessoas. Este trabalho pretende investigar de que maneira esses desejos são inculcados - e considero meus desejos freqüentemente como exemplos. Começo considerando a relação entre o priva do e o público na esfera dosdesejos; tento encontrar elementos para investigar o que significa dizer que o pessoal é político (1-6, 10-12). Depois de algumas observações prelimina res sobre corpo, desejo e soberania (7-9), passo então a considerara relação entre a politização dos desejos e a pomografia (13-15). Isso me permite rapidamente intro duzir a lguns elementos do modelo a ser esboçado que dizem respeito ao corpo e à confluência das ecologias (16-20) diagnosticadas por Guatta ri. ${ }^{2}$ Depois de a lgumas observações sobre a política dos estupros (21-25) dirijo-me ao tema da maneira como concebemos a quilo que é natural (26). Em seguida (27-35) considero o modo como nosso corpo (e suas políticas, eróticase ecologias) toma-se nosso. Nesse ponto estou em condições de procurar esboçar explicitamente o modelo (36-37) e concluir considerando algumas de suas conseqüências.

1. Desejos muitas vezes são entendidos como exigindo uma esfera própria, uma esfera especializada: muitas vezes entendemos o desejo pertencente a um domínio privado. Gostaria de começar a pensaro desejo em sua relação com essa articulação de esferas. O que significa contrastar o privado e o político? Muitas vezes pensamos de um jeito quando tratamos de alguma coisa pública, e de um outro jeito quando pensamos privadamente. Um exemplo dessa dicotomia pode ser encontrado na forma como Rorty ${ }^{3}$ distingue auto-criação, ou a utonomia, de um la do e solidariedade de outro. Rorty pretende entender a solidariedade e a autonomia como valores que guiam nosso pensamento - e entende que esses guias são tais que apenas um deles é compatível com a a rgumentação (e, presumivelmente, com o debate político). Ele diz que

não há modo de juntar auto-criação e justiça no nível da teoria. O vocabulário da auto-criação é necessa riamente privado, não-compartilhado, ina dequado para a argumentação. [...] As demandas da auto-criação e da solidariedade humana são

${ }^{4}$ RORTY, 1989, p. xiv-xv. Tradução igualmente válidas, e ainda assim incomensurá veis. ${ }^{4}$ 
${ }^{5}$ RORTY, 1999. Ele concorda com Robert BRANDOM, 1999, que sua distinção entre vocabulários de autonomia e vocabulários de solidariedade é problemática e pode serperigosa.

${ }^{6}$ Ludwig WITTGENSTEIN, 1968, I, 256-304.

${ }^{7} \mathrm{Na}$ Argentina de Videla, quando o chamado "Proc esso" militar tentou a trair os polític os civis, estes torciam para que a luta contra a chamada subversão não fosse ao estilo Pinochet com a ssa ssina tos públic os. Em um cená rio desses, os polític os teriam de justific ar ou condenar os atos do Processo. Os desaparecimentos lhes convinham mais: instalavam um clima de terror uma vez que critérios e escolhas nã o precisavam serem nenhuma medida publicamente esc rutináveis - mas prescindiam de um discurso público. A a rena privada parece muitas vezes como o espaço debaixo do tapete para onde colocamoso que não pode ser julgado publicamente. Durante o período, os desaparecimentos foram escolhidos porque pareciam subversivosaos olhos de algum grupo militar (embaixadores que estavam muito próximos de Videla, quando iam a Buenos Aires, poderiam também desa parecer --- como foi o caso de Hidalgo Solá, embaixador na Venezuela desaparecido em Buenos Aires em julho de 1977). Aquilo que parecia subversivo a um grupo suficientemente armado e poderoso dasforçasamadasera subversivo. Para uma exposição mais detalhada do episódio, consultar, por exemplo, Marcos NOVARO e Vicente PALERMO, 2003, p. 106-220.
Incomensuráveis, mas compatíveis porque os vocabulários públicos e os vocabulários priva dos têm diferentes funções em nossas vidas. Ambos nos a judam a lidar com certas situações. Acontece que, se Rorty está certo, temos que ter já uma divisão entre as situações a propriadas para cada tipo de vocabulário. Precisaría mos ter uma espécie de ur-vocabulário, um vocabulário fundante, que proceda à separação entre o que é apropriado para cada vocabulário. Rorty, sabidamente, posic iona-se muita s vezes contra voca bulá rios considera dos privilegiados, que de alguma forma são tomados como mais próximos de como as coisas são - representações privilegiadas. A inexistência de vocabulá rios com direito a privilég ios especia is insinua uma pergunta assim: que metavocabulário poderoso poderia instituir a separação entre a s esferas públicas e as esferas privadas? A instituição de separaçõesé feita e desfeita desde dentro de vocabulários por nós, que de alguma forma traficamos vocabulários. Penso que a afirmação de que o pessoal é político deve ser pelo menos uma maneira de negar a incomensurabilidade de que fala Rorty. ${ }^{5}$

2. Há um sentido de privado associa do a o que não é corrigível: a o que está para a lém do escopo de qualquer correção. Muitas vezes, são esses os conteúdos privados que são exorcizados a o longo do trabalho de Wittgenstein nas Investigações (PU, 1, 256-304). ${ }^{6}$ Aquilo que é privado é a quilo que não precisa ser visto, explicado, justificado, divulgado. E também não precisa ter mais do que uma a parência de correção para quem de alguma forma tem a cesso a ele. Muitas vezes sensações são associadas a o que é privado. Pode-se argumentar que tudo a quilo que escapa ao controle público, no qual nenhuma instância pública pode intervir, está alheio a normas de correção. Assim, por exemplo, quando dizemos que a vida privada deve ser reservada, estamos estabelecendo um lugar de onde não repercute nada, um pequeno casulo. ${ }^{7}$ Quando os passos de uma ação não podem ser examina dos, não podemos colocá-los sob o escrutínio de normas de qualquertipo. 0 priva do pa rece a qui próximo de um terreno de arbitrariedade completa. Aquilo que fica completamente escondido pode ter o luxo de nem sequer p recisar ser inteligível.

3. Podemos pensar na distinção entre privado e público como a distinção entre cama, carteira e vida familiar de um lado e rua, trabalho e vida na sociedade civil de outro. É assim que, primariamente, eu a entendo. Porém muitas vezes o privado é a diferença entre nós e qualquer 
dosgrupos de identidade a que pertença mos- por exemplo, porque pertencemosa outrosgruposta mbém: temos gênero, mas temosclasse, etnia, esc olha sexual, raça ta mbém. Amos $\mathrm{O} z,{ }^{8}$ propondo uma retific ação do muito citado diagnóstico de John Donne de que todo homem é uma ilha, escreve que nenhum homem e nenhuma mulher são ilhas, mas todas as pessoas são penínsulas, um la do próprio, um la do púb lic 0 . Todas as pessoas estão parcialmente conectadas com as outras, mas não completamente. A solidão, o foro íntimo, as motivações que me atingem podem deixar de atingir outras pessoas. Alguns movimentosno espaço das prátic as públic as são pessoais: são próprios. 0 que é próprio é, pelo menos, uma posição específica na assembléia de pessoas: que horizonte podemosobservar, do ponto onde estamos. Nesse sentido, no sentido em que somos península s, o pessoal não deixa de serpolític 0 . Masparece que ele invoca uma política diferente, que não é apenas a polític a das manifestações de rua - veremos que talvez não seja apenas a polític a dos grupos de identidade. Não se trata de organizar partidos ou movimentos, de escolher, mas de nos movimentar dentro dos cenários em que estamos. Trata-se de uma política diferente?

4. Dizemos: pecunia non onet. O dinheiro, que controla e substitui a maioria das nossas polític a s emociona is - a maioria do nosso contato com as outras pessoas -, esconde sistematicamente a teia de relações pessoais que fazemos para sobreviver. 0 dinheiro deixa as classes, o prestígio, a distribuição de privilégios recônditos. 0 dinheiro esconde um conjunto de relações econômic ase força uma estrutura competitiva em que nã o importa de onde o dinheiro vem - seu cheiro. 0 dinheiro permite que pensemos na economia como independente de nossas outras relações

${ }^{9}$ Geneviève VAUG HAM, 1997. com aspessoas - como Gen Vaugham ${ }^{9}$ uma vez sentenciou, a troca monetária institui uma linguagem independente e de poucos recursos para que negociemos a quilo que entra na esfera ec onômica. Podemos pensar, a naloga mente, que a idéia de que as pessoas buscam prazeres nos permite tomar a erótica independente de nossas relações com as pessoas. A erótica, como a economia, fica instituída como uma esfera independente; e, assim independente, fic a liberada de se apresentar a um escrutínio por parte de normas socia is extemas a elas. Nesse sentido, e pensadas assim, elas fic a m parec endo a utôno mas como muitas vezes quer parecer a esferas privadas.

5. Existem partes da nossa vida que não concemem a ninguém? Pensamos assim quanto aos nossos bens privados: aquilo que é uma propriedade privada pode ser 
usada como aprouver apenas a quem dispõe da propriedade. Nenhuma outra voz é relevante. Pensamos assim quanto a nossa vida privada: aquilo que é de nossa vida privada dispomos como nos aprouver, apenas a nós. É como pensamos no dinheiro que temos no bolso na maioria dos casos: gastamos como decidimos gastar; o domínio privado é um domínio do nosso arbítrio - livre. Aquilo que é priva do é muita s vezes entend id o como sendo ja ma is passível de revisão, como sendo a lguma coisa que não pode ser julgado como correto ou incorreto - não pode, portanto, ser comigido - e que não deve sercoloc ado em xeque. Aquilo que é público pode ser questionado, pode ser julgado e é onde pode haver julgamentos de responsabilidade. Aceito esse contraste entre o público e o privado, parece que há um sentido de liberdade que repousa na nossa capacidade de fazer escolhas que podem ser vista s como acerta das - a liberda de na esfera pública --- e há um sentido de liberdade como puro exercício de nossos desejos sem restrições - a liberdade na esfera privada. Vivemos, de acordo com essa imagem, uma vida dupla e, portanto, temos uma dupla liberdade. Essa imagem permite que as proprieda des privadas seja $\mathrm{m}$ usadas como livremente (no sentido privado) escolhem quem tem a propriedade: uma vez que o dinheiro entra na ca rteira (ou na conta bancária), não se deve mais restring ir o seu uso. Essa imagem ta mbém permite que a vida pessoal possa ser gerida livremente (no sentido privado). Uma ima gem a ssim implica o privilég io da não-responsa bilida de sobre o dinheiro que sai da carteira e sobre as conseqüências das escolhas pessoa is. A esfera priva da fic a livre de escrutínio: o privilégio de não ter responsabilidade sobre as conseqüências dos nossos a tos privados é o privilégio de quem fica fora do escopo do escrutínio. A imagem de que o privado é esfera diferente do público favorece quem não precisa justific a ra quilo que faz porque faz em uma esfera privada. A imagem desfa vorece quem não pode fazer demandas ou reivindic ações porque elas atingem uma esfera privada. A separação entre público e privado interessa a quem pode usar privilégios que ficam sem serem questiona dos: privilég ios exerc idos entre qua tro paredes, privilégios tornados possíveis pelo dinheiro na carteira. Não a tribuir responsabilidade ao que se faz na esfera secreta incapacita as demandas de quem não dispõe desses privilégios. Politiza ra erótica e a economia é conectá-las com as dema is interações entre as pessoas e a história delas. Politizar vidas pessoais é supor que não existem essas províncias onde nenhuma outra voz pode ser escutada; onde a penas a minha vozfala, comanda e é obedecida. Negarque haja províncias só minhas, mesmo 
${ }^{10}$ WITTGENSTEIN, 1968, II, iv.

${ }^{11}$ Interessante aquia observação de Ondina Pena Pereira (em conversa) sobre um grupo melanésio que, após contato com o Ocidente, diz que os ocidenta is Ihes trouxeram a idéia de corpo e não a idéia de espíito.

${ }^{12} \mathrm{Cf}$., por exemplo, Alexander LOWEN, 1958. na minha vida pessoal. (E ainda assim minha vida pessoal é minha: me diz respeito.)

6. Uma vez eu participei de uma discussão sobre como as mulheres bonitas são favorecidas a o procura rem emprego. Podemos legislar sobre as obrigações dos empregadores e, assim, impedi-los de descriminar quem não apresenta beleza. Muito mais difícil é atuar sobre a vida pessoal dos homens que escolhem estar a penas em rela ções a fetivas ou sexua is com as mulheres bonitas. Não podemos-a qui começa a esfera privada, um véu de Maya que esc onde o que sup osta mente nã o deve ser exa mina do: quanto a isso, nenhuma vozpode ser escutada e os desejos devem ser deixados em paz. E, no entanto, na medida em que nossos desejos escutam outras vozes, eles são politizá veis.

7. Relatos etnográficos de uma tribo de índios brasileiros que andam sem roupa contam que os índios sentenciam: "em nós, tudo cara". Se tudo é cara, nada é pomografia. A pornografia ensina a separara cara do resto do corpo, a cara não pode ser olhada com olhos pomográficos. O corpo, por outro lado, expressa muito pouco, apenas obedece (ou não obedece) às norma s do que é desejável. Wittgenstein escreveu que "o corpo humano é a melhor imagem da alma humana". ${ }^{10} \mathrm{E}$ nós não vemos a alma na maiorparte do corpo; vemosapenas o que uma certa pomografia ensina a ver. Trata-se de uma maneira de ver os corpos que deixa os desencantados, sem a Ima, no seguinte sentido: fic am exilados de tudo de pessoal. ${ }^{11}$

8. Muitas vezes para nós nosso corpo a parece como terra incognita. Terra desconhecida e que, no entanto, responde a nossa maneira de vivere - parece - de forma cada vez marcada. Penso que nossos corpos, assujeita dos por nosso controle e pelo qual somos responsáveis, vão gradativamente, tomando-se mais e mais a nossa cara. Meu corpo, parece, responde mais a minhas angústias, está ma is bem sintoniza do com meus a fetos e exprime ele mesmo meus próprios confortos e desc onfortos emociona is. Penso que, com a passagem do tempo, o corpo fica ma is dominado, não pela nossa vontade, mas por nossas motivaçõese pelos nossos esta dos emocionais. Nosso corpo se toma mais e ma is a melhor imagem de nossa história pessoal - de nossa capacida de de sentire dossentimentos que o ambiente e as pessoas a nossa volta provocam. ${ }^{12}$ Penso entã o que os corpos, com o tempo, tomam-se ma is visivelmente efeitos da maneira como vivemos; frustrações, 
${ }^{13}$ No filme Monique, de Valérie Guignabodet (2002), uma boneca que parece muito uma jovem mulher é comprada por um homem que se separa de sua esposa. Monique, a boneca, é um corpo pura materialidade, mas com uma história que se supõe ser a história dos afetos e concessões de uma garota a traente simula da nele. Não é um corpo qualquer ou um corpo em geral porque não há corpos sem uma história de afetos e concessões. Mas é um corpo que agora se toma isento de política - submisso à erótica e à política do dono. 0 dono da boneca é que assujeita o seu corpo, e assujeita-o completamente. Sua ex-mulher, em uma crise de insegurança, diz "mas ela poderia ser sua filha...". Claire, a exesposa tenta entender o exmarido pensando no que Monique não faz: não reclama, não faz jantares, não lava a louça, não cozinha, não fic a indisposta. O marido resolve assumi-la completamente: era um corpo assim que ele queria. o filme parece para mim um retra to de um tipo preponderante de desejo masculino.

${ }^{14}$ Cf. David HUME, 1911[1740]; Donald DAVIDSON, 1980.

${ }_{15}$ Cf. por exemplo John MCDOWELL, 1998; Richard MORAN, 2001. a ceitações incompletas, desgostos e relações a mbíguas com outras pessoas são a fetosque fazem adoecere fa zem morrer. O processo acontece quando envelhecemos, quando nossos corpos deixam de ter a juventude na qual eles sejam talvez menos um retrato de nós, sejam talvez menos assujeitados por nossa vida emocional. Os corpos que a prendemos a desejar com a pomografia são corpos jovens. Talvez sejam corpos que não sejam a cara de ninguém. A virgindade continua a ser desejável: a virgindade emociona ${ }^{13}$; como o desejo pedófilo que seja pautado pelo desejo porcontrolaro que é vulnerável, por aquilo que nem sequer se assujeitou a si mesmo. A pomografia, também nesse sentido, separa os corpos do que eles expressam. Ela toma possível a desconexão de nossa vida erótica do resto de nossas vidas. Um erotismo que tratasse com sujeitos e com corpos que são a cara de a lguém seria um erotismo espalhado portodos os terrenos da nossa vida emocional.

9. O desejo parece ser muitas vezes pensado como endereçado no corpo. O corpo, por sua vez, é uma propriedade pessoal de alguém - como pessoais e ina liená veis são as vidas menta is e, portanto, os desejos. De um lado, ouvimos a sugestão de que o pessoal é esfera a utônoma, privada, a lheia, por conseguinte, a os esforç os de politização. Por outro lado, se o desejo não é inteiramente privado, aceitamos que ele trace caminhos inescrutá veis. A separação entre os desejos como itens priva dos e o resto de nossa s vidas como politizá veis sepa ra também os nossos corpos - lócus dos desejos - de nossa capacidade de soberania. Existem muitas razões para rejeitar a imagem tradicional da fraqueza da vontade diante dos desejos ${ }^{14}$ em favor de uma imagem onde nossa sobera nia se rela ciona com nossos desejos de uma ma neira ma is complexa. ${ }^{15}$ Gosta ria de propor um modelo da esfera dos desejos - e paralelamente do que fica refletido em nossos corpos - que não a considerasse como privada no sentid o de a lheia a qualquer esc rutínio político e, a o mesmo tempo, que respeitasse as intuições de que ela não pode ser apenas um reflexo de nossa soberania pessoal. Esse modelo, que ficará claro no resto do trabalho, entende que os desejos respondem sempre a minha esfera pessoal, às subjetivida desa minha volta e à história da nossa espécie em seu ambiente.

10. O que significa dizer que o pessoal é político? Não se trata de uma redução do tipo que permite que abandonemos todo discurso acerca do que é pessoal porque, no fim das contas, tudo é político. Podemos dizer 
que o disc urso polític o trata, prevê, cura, explica, entende e toma possível tudo o que o discurso pessoal trata, cura, explica, entende e toma possível? Quero dizer que não, não pode ser nesse sentido que o pessoal é político. Em que sentido entã o?

11. Se o pessoal é político então o pessoal não é estétic 0 , por exemplo? o pessoal, eu tento dizer, tem uma dimensão polític a. Não queremosque o sujeito desapa reça, tragado pelo objeto que é pensado - queremos que as subjetividades não se tomem objetividades (nem mesmo objetivida des potencia is) para que ela s possam ser polític as. As subjetivida des - feitas de um ma terial púb lic o, penínsulas de Oz - carregam capacidades políticas. Penso que se tra ta de negara incomensurabilida de entre uma dimensão pessoal e uma dimensão política; negar a incomensurabilidade não é por si só a firmar que é possível que uma dimensão se reduza a outra. Não se reduz; nem sequer me parece inteligível o que seria uma redução assim. E parece que na comensurabilidade entre o político e o pessoal é que surge o espaço para as diferenças. Pergunto-me como podemosformulara polític a e a erótic a dessas diferenças? $\mathrm{E}$ as diferenças não são nem dadas e nem irreversíveis. Não são irrevogá veis em ponto algum. $E$, no entanto, isso não nos leva a uma a rquitetura da vitória ou do convencimento - da tese vencedora, seja de fato ou de direito. Minhas crenças afetam as crenças das outras pessoas como meus desejos a fetam os desejos das outras pessoas. Porém no caso dos desejos - pelo menos no caso dos desejos - não parece que se trata de um campo vencedor e um campo vencido, um campo convencido. Meus desejos contagiam, mas o contág io a tua sobre um outro corpo. A tentação do território conquistado, ou do convencimento, é, no caso das crenças, a tentação de pensar em nossas crenças isolada mente, como por vezes pensamos em teses que podem se sustentar a penas por demonstrações. Mas as teses não podem ser entendidas sem outras crenças e nossas crenças - nossas teses freqüentemente não podem ser identificadas senão por meio das demonstrações de que fazemos uso para mantêla s em mente: crenças são função da demonstração, mas ta mbém as demonstrações são função das crenças que temos (e, mesmo, da tese em questão). A tentação do território conquistado, ou do convencimento, parece ser também no caso do desejo um produto da idéia de que um desejo nosso possa ser isolado dos demais e do resto de nossa vida; os desejos das outras pessoas a tuam sobre mim atuando sobre o pano de fundo dos meus desejos, dasminhas crenças. Pa rece cla ro que afeta mosas pessoas; 
de alguma maneira afetamos as crenças e os desejos das outras pessoas; não é uma crença específica que muda, não é um desejo específic o que muda. Não é um desejo específic o que passa de uma pessoa para outra - em outra pessoa, o desejo assume sempre uma outra identidade.

12. Não pa rece fá c il ind ividuar desejos. Ag imos sobre diferenças quando nosso desejo contagia. É essa epidemiologia que tem uma política: não é alheia a quem tem podere privilégios (e a ribalta e o megafone). A polític a dos desejos é uma espécie de epidemiologia de quantidades massivas. Um desejo é sempre composto de um pano de fundo de outros desejos que compõem toda uma cena (com outros itens da nossa subjetividade). Afetar os desejos das outras pessoas - e o combate emocional, simbólic o e prático dosfeminismos se inserem a qui - é a fetar g randes qua ntida des de elementos nas subjetivida des das pessoas. Nenhum desejo nos move sozinho; nenhum desejo pode ser transformado sozinho.

13. A esfera de desejos parece por vezes ter todas as suas portas e ja nelas abertas. Pa rece que cada desejo pode ser transformado, ainda que não possamos alterar todos os nossos desejos a o mesmo tempo. Os desejos formam um composto em que cada um só pode ser entendido - e só pode atuar - sobre o pano de fundo dos outros desejos. Se pudermos confiar nessa propriedade transformável dos desejos, essa plasticidade dos desejos de cada um de nós, temos a indicação de um caminho na política dos desejos: eles não são natura is, não estão a marrados em nós com laços de aço. Acredito que os feminismos são pedagogias do desaprendizado das pomografias masculinistas. Espero que eles atuem sobre meus desejos. Observo meus desejos como uma a rena em que minha soberania, minha política, a natureza e minha educação estão presentes. Observo o que faço com a pomografia que coloniza alguns dos meus desejos dentro dessa arena.

14. Fic o querend o toc arnospés, nas pemas, no corpo dasmulheres - e uso a pornografia, pelo menosna sua forma mental. A esta altura, não me lembro mais se algum dia fui mesmo a um cinema pomô, como o cine Rit, que tem também pessoas fazendo sexo no palco. ${ }^{16}$ Não sei se é só ima gina ção que a lgum dia entrei no cinema, fiquei exc ita do e entediado e saí dele me sentind o miserá vel. Não importa. Mas dentre os homúnculos dentro de mim, parece haver pelo menos um que tenta ser complacente com a 
pomografia. Passo a chamá-lo de Ritículo. Tenho também outros homúnculos dentro de mim, porexemplo, a quele que abaixaria a minha cabeça quando eu saísse miserável do cine Ritz. Esses homúnculos me dizem que qualquer pornografia inventa desejos em mim, desejos que esquartejam as mulheres, as enxergam como um corpo, desejos que me fazem associar prazer e dominação, o cupação, subjugação. Esses homúnculos têm prazer com gente como John Stoltenberg ou Andrea Dworkin. Um deles pode se chamarDworkínculo. Osdois, Ritzíc ulo e Dworkínc ulo, são homúnculos que vivem discutindo dentro da minha cabeça, na pele da minha mão, entre osporos das minhas costas. Eles têm diálog os a ssim:

Riтźc ulo: A pornografia é uma escapatória para o erotismo. Quando meu desejo de trepar é muito grande, me masturbo; às vezes o desejo fic a a inda ma is satisfeito com as imagens e os sons da pornografia. Não sei se a pormografia satisfa z meu erotismo, mas pelo menos me livra das minhas urgências...

Dworkinculo: Mas a que preço? Ela me ensina a desejar a dominação, a erotizar o controle, a gostar do jogo de provocar e conquistar. Eu acho que a pomografia é um desperdício de erotismo. Aquilo que é mais pulsante e que mais nos sacode é colocado à disposição de um roteiro fixo em que eu sou o homem que domina a presa depois que ela me tenta, se insinua, pede para ser dominada e eu a domino. Cada vezque eu vejo uma pomografia, fic am reforçadas as lições de que as mulheres querem ser dominadas, não importa o que elas digam. A pomografia a parece como a a utoridade a noscontaro que as mulheres realmente querem...

Riтźculo: As mulheres que eu conheci fora da pomografia raramente querem apenas serem dominadas; esta é uma fantasia pomográfica.

Dworkinculo: Mas por que é que eu quero dominar as mulheres, possuí-las, fodê-las, tê-las como objeto da minha conquista que me faz sentir fiel aos princípios da minha casta masculina?

Ritúculo: Sei lá se eu quero isso tudo... Gosto de sexo. Quero as mulheres, às vezes gosto de dominá-las como na pomografia, a pomografia realiza esses desejos...

Dworkínculo: Masa pomografia enfiou esses desejos em mim! Riтúculo: Não sei se meus desejos foram criados por uma pedagogia pomográfica ou uma matriz misógina ou sei lá o quê. Mas eu desejo sexo e a pomografia me mostra o que eu desejo, mesmo que a pomografia seja o meu desejo por definição. Hoje eu desejo corpos femininos sensua is e lânguidos, não sei de onde isso veio, mas sei que desejo essas coisas. 
Dworkínculo: Eu a prendi a desejar essas coisas, mas não é só isso que eu aprendi.

Riтźculo: O que mais eu a prendi a desejar?

Dworkínculo: Eu acho que a pomografia ensina a desejar porque o desejo é contagiante. Não somos alheios às pessoas a nossa volta, aprendemos a ser o que somos olhando outras pessoas e pensando no que elas fazem e no que elas gostam. É por isso que a pomografia pode ser tão eficiente - desejos são a prendidos, aprendemos com a s outras pessoas o que é desejá vel (e o que não pode ser desejável). É uma lição difícil, precisamos anos para a prender e muitas pessoas não aprendem direito - acho que ninguém aprende direito. $E$, no entanto, talvez nós não tenhamos nenhum desejo a não ser aqueles que aprendemos vendo as outras pessoas desejarem. Para a prendermos a desejar muitas coisas, temos que ter conta to com muitas coisas. Temos que ter um regime plural de desejos.

RIтźculo: É estranho, parece que nossos desejos não são quase nunca realmente nossos.

Dworkínculo: $E$ talvez nenhum elemento da nossa cabeça seja realmente todo nosso. Nossa cabeça é parte de um sistema material de dominação sexual das mulheres que dispõe dos nossos corpos para erotiza r o conflito da nossa casta masculina com as mulheres. Uma base dessa dominação é que as mulheres são caças, são presas - e a pomografia é uma representação da sedução e da posse. Meus desejos foram forjados em um regime assim; e, no entanto, eles são pelo menos em parte meus.

Rıтźc ulo: E o que faço com meus desejos? Reprimo, realizo ou fico em um meio termo morno que é a masturbação? Quando entro no clima da masturbação, só a pomografia me interessa; não penso mais que as diferenças de comp orta mento sexual são instiga ntes e como ela s podem ser subversivas, não penso mais nos trechos dos livros que me fazem chorar - procuro os trechos de romances em que há alguma coisa que me excite, procuro imagens de sexo ou procuro pensarminha própria pomografia... Olha, Dworkínculo, eu quase sempre estou pronto a entenderos desejos sexuais que eu tenho como sendo em grande medida fabricados pela pornografia, que é parte da maneira frustra nte como vivemos as coisas eróticas. Há um homúnculo dentro de mim, o Naturículo, que insiste que meus desejos simplesmente vieram assim. Mas não dou muita trela para ele. Entendo meus desejos como tendo uma história associa da com o resto do mundo e, no entanto, desejos aparecem muitas vezes como urgências, como a lguma coisa que me impele a fazeralguma coisa. Nesses casos, eu faço o meio termo; mas me pergunto se faz bem 
ficar na opção moma, melhor seria contratar uma puta e... pronto!

Dworkínculo: Acho que contratar uma puta seria reforçar ainda mais o esquema dos desejos que me frustra. Você sabe, Ritzículo, minha agenda é me curar da pomografia. Talvez, eu penso às vezes, se eu começasse a a gir com as mulheres de um outro modo; assim, deliberadamente, depois com o tempo o meu próprio comportamento me contagiaria. Eu começaria negociando cuidadosamente com meus desejos e depois aprenderia a não mais me excitar com mulheres que seduzem para serem controladas..

Riтúculo: Tenho vonta de de trepar. Esta conversa me lembra sexo e, depois que este diálogo começou a ser registrado, dei para procurar pomografia na rede. Ah... Agora achei um casal trepando em várias posições e ela contando assim:

Logo no elevador ele chegou mais perto e a gente começou a se beijar, senti a mão dele entrando por baixo da minha saia e sentindo a minha bundinha. Comecei então a mexer no pau dele por cima do short, que já fazia um volume bem duro e gostoso que me deixou louca. Estava totalmente duro, cada centímetro. Ainda no corredor do prédio a gente se pegava, se beijando e passando a mão um no outro. Quando entramos no ap ele me levou pro o quarto e tirou a camisa, foi ótimo ver o seu tórax, e já ir explorando o corpo dele, era definido e gostoso, nem precisou de mais incentivos pra eu já tirar toda minha roupa, começando pela saia e revelando já minha boceta pra ele. Depois de eu tirar a blusa, ele tirou o short e a cueca e nossa, quando eu vi aquela pica! Dá vontade de gemer só de pensar. Que tesão... Logo falei para ele que era muito tesudo aquilo, que a rola dele estava muito dura. Só de escrever já estou toda molhada. Na hora eu já me virei e fiquei de quatro, com os braços na cama apoiada, oferecendo minha bunda pra ele. E aí senti pela primeira vez a pica dele esfregando ali atrás, estava bem quentinha e me deixava louca, ficamos roçando um no outro assim um bom tempo, ele de pé me encoxando e eu apoiada na cama. Logo ele começou a meter, então comecei a gemer muito, já estava caindo na cama, falei que o pau dele metia muito bem e não sei se foi impressão, mas senti que ficava mais duro ainda dentro da minha boceta. Ele me pegava pela cintura, o que me deixou excitada até hoje; adoro que peguem na minha cintura e ele metia com força acabando comigo 
Leio esse relato de uma mulher, vejo as fotos do corpo dela, e o pau fica duro e tenho vontade de me masturbar. Começo a me masturbar até gozar... [pausa] Dworkínculo: Depois de gozar, parece que eu recomeço a pensar naquilo que ficou enfiado debaixo do tapete enquanto eu estava com toda atenção na pomografia. Começo a me perguntar por que essa mulher escreve isso. Exibicionismo, ela diz, isso a excita. Ela escreve o que os homens querem ouvir, talvez ela faça o que os homens querem que ela faça - e talvez esteja aí a excitação dela. Mas parece que o desejo dela não está bem aí, ela não pode ter desejos de sa tisfa zer os desejos dos homens - seus desejos são independentes!

Rıтźculo: Às vezes, Dworkínculo, parece que você deixa o Naturíc ulo tomar conta de você. Os desejos dela também sã o construídos pela pornog rafia...

Dworkinculo: Claro, mas é por isso que dá vontade de promover uma agenda de cura da pomografia. Talvez nós devamos libertar nossos desejos da imagem de sexo: reerotizar o resto de nossas vidas e deixar nossos desejos esta rem presentes em conexão com tod o o resto de nossa s vidas: enxergar as pessoas ao invés de despedaçar os corpos. Experimentar desejos que não tenham roteiro fixo, que não envolvam sedução e conquista, que integrem nossa genitália com nossas emoções específicas com respeito a cada pessoa...

Riт́ćculo: Sim, mas o que fazer enquanto esse projeto não a contece? Reprimir meus desejos de gozar vendo corpos sendo possuíd os? Olha, Dwor, eu tenho evita do rea lizarmeus sonhos de domina ção orienta dos pela pomografia. Muitas vezes não sinto que não posso fa zero que eu quero porque não quero apenasisso: na maioria das vezes, meus desejos são outros, são desejos de contato com as pessoas. Mas como posso parar de me masturbar com pornografia quando o desejo de sexo puro aparece? Eu sei que você a cha que sexo puro é uma maneira ruim de trataros desejos pomográficos, realmente, mas você sabe o que eu quero dizer...

Dworkínculo: Sim. Mas olha, Ritz, eu rea Imente nã o sei o que devo fazer, a punheta com pornografia me incomoda. Mas me incomoda essa fragmentação que parece parte da maneira ma sculina de pensar: é como se nossas experiências pudessem ser fratura das, litera Imente seus ossos quebra dos, examinamos os pedaços e esquecemos dos ossos, exa minamososossose esquecemos do como. Me incomoda essa coisa de que meu pau é de um homúnculo, meu coração é de outro. Essa hipera tomização me corrói. Há uma parte de mim que fica esma ga da quando vejo imagens de gente trepando, me excito e me masturbo - gente que 
17 Personagens do meu poema "Sem paciência, sem letargia" publicado em comunista (BENSUSAN, 2005). são corpos sensua is, é o que importa. Queria ter minha vida sexual mais integrada com as coisas que me encantam queria apenas me excitar com elas. Fico com uma ânsia enome de me livrar desse legado da pornografia...

Ritziculo: Dwor, acho que nós temos medo desses homúnculos que são o Assimmesmo e o Deixaestar. ${ }^{17} \mathrm{Um}$ medo de deixar de se preocupar e simplesmente se entregar ao que parece que desejamos, como muitos homens dão a impressão de fazer. Mas às vezes eu tenho medo desse medo, tenho medo de corrermos tanto do Assimmesmo e do Deixaestar que acabemos parando de fazer outras coisas, de ter prazer

Dworkínculo: Acho que é possível subverter a minha própria estrutura de desejo a partir de dentro a firmando algumas coisas, ao invés de apenas proibir a pomografia. Ousar, ousar integrar meu erotismo no resto da minha vida, ousar liberar as energias eróticas de to do o meu corpo - afirmar tanto um prazer corporal não-pornográfico que a pornografia fique parecendo sem cor, desinteressante, pálida diante dessas outras experiências...

Ritziculo: Bacana, Dwor, mas você mesmo disse que os desejos contagiam. Parece que o prazer pornográfico é um prazer que eu posso ter sozinho, sem me comprometer com ninguém, sem dependerde ninguém - a não sertalvez de um suporte de imagens a qui e ali. Mas como eu posso reafimar desejos altemativos dentro de mim sozinho? Dworkínculo: Eu sei, às vezes sinto-me tentado a promover imagens e textos eróticos alternativos; uma espécie de contrapornografia. Às vezes tento me masturbar pensando em imagens muito diferentes daquelas que a pomografia promove. Tem vezes que dá certo.

Rाтúculo: Masa punheta é muito pouca a ção a firmativa para empalidecer a atração da pomografia que às vezes toda hora, às vezes uma vez por semana, reaparece!

Dworkínculo: Pa rece que não posso mudar meus desejos sozinho. Tenho tido algumas experiências fantásticas com as mulheres que conheci, sobretudo desde que comecei esse tortuoso caminho de me curarda pomografia.

Ritzic uLo: Mas aí há um problema: as mulheres rea is têm que oferecerma is prazer, ma is erotismo que o que a pornogra fia oferece para que a pornografia empalideça. Por muitos dias, às vezes semanas, ela empalidece, mas não para sempre. Parece que ela volta a me ocupar. E ela não aparece somente com textos e imagens explícita ou implicitamente pornográficas, ela aparece no comportamento que às vezes eu tenho com as mulheres e elas por vezes realimentam meus desejos os ma is pomográficos - por exemplo, pedindo assim: me estupra. Eu me pergunto, é claro, de onde vem essa fala.. 
18 O filme Le Pornographe, de Bertrand Bonello (2001), ilustra uma melancolia de quem vê e produz pornografia. Jacques, uma pessoa que começou a fazer pornografia pelo que parecia ter de subversivo logo depois de 1968 e que depois se profissionalizou, vive a crise de ter que voltar a filmar pomô depois de uma longa ausência. Sua melancolia foi pelo menos em parte ativada pelo filho adolescente que, ao saber que ele fazia pornografia, o abandonou. Jacques, de fato filma o roteiro dos seus sonhos L'animal, em que uma mulher é caçada em um grande bosque por homens que querem fazer sexo com ela - trata-se de uma trama pomográfica arquetípica e que aparece muitas vezes nas metáforas de Andréa Dworkin da mulher pornografada como presa. Em uma entrevista, Jacquesé perguntado se prefere filmar sexo ou cenas dra máticas. Ele responde: "a felação; na felação não há apenas dois órgãos, mas uma cara. A cara é a última fortaleza do que é humano". A pomografia a parece aqui também como uma oposição entre sexo de um lado e expressividade do outro. Os órgãos (genita is) estã o para a lém da fortaleza do humano.
Dworkínculo: A pomografia está na cabeça de todo mundo... RIт́ćculo: Mas quem disse que as mulheres querem todas se curarda pomografia? Aquela mulherda rede, porexemplo, pode ser que ela esteja bem feliz com seus desejos (a inda que talvez em dez anos queira desejar coisas muito diferentes).

Dworkinculo: Não quero curar todo mundo da pomografia, este é apenas um projeto para mim mesmo. Claro que nã o posso me transformar sozinho, mas talvez não precise que toda a humanidade de uma só vez abandone a pomografia - talvez me sejam suficientes apenas alguns gatos pingados em tomo de mim; uma massa crítica! Riтúculo: Mas, Dwor, se está na cabeça de todo mundo, quem vai me contagiar a cura? Realmente, isso me incomoda muito.

Dworkínculo: A cura tem que vir do contágio dos exemplos. Ou seja, há fissuras na ordem pomográfica estabelecida. Proponho que tentemos enfiar a mão, o braço, as pemas (e o pau!) nessas fissuras.

Ritzículo: Mas como? As mulheres que pedem para ser estupradas (ou comidas, ou fodida s ou a rrebenta das) não podem junto comigo fazera tal ação a firmativa super-super que vai empalidecer a pomografia porque elas têm uma perna dentro da fissura, mas outra perna fissurada nos roteiros pomográfic os!

DwoRKínculo: Éverda de, Ritz, não há ninguém que, sozinho, pode nosconduzirpela mão para fora dos domínios da pomografia. Porém, também penso que ninguém aprendeu apenas os desejos pomográficos. Há outros exemplos em todo mundo; os exemplosque eu intuo quando a parece aquela melancolia pós-pornografia. ${ }^{18}$ Não são as mulheres que redimem, mas são os momentos das vidas das pessoas em que elas desc onfiam que sua vida erótica fica bitola da e a mordaça da pela pornografia - e que elas podem querermais...

Riтźc ulo: Dwor, tenho medo de Assimmesmo e de Deixa estar. Quase sempre que me masturbo tenho medo de estar desistindo um milímetro ou dois de ter uma vida erótica mais descolada da pomografia. De me agarrarao prazer de foder, reconhecer que quero isso; reconhecer que 0 desejo da pomografia é meu e pronto. O resto do mundo terá que se adaptaraos meus desejos...

Dworkínculo: Tenho esse medo também; eles são fortes e poderosos esses homúnculos. Nos a rrasta m pelos cabelos. Mas eles prometem muito pouco para o meu futuro; eles oferecem apenas um gozo fácil e a frustração de erotizar uma guerra mesmo que eu não goste de guerra. Eu quero confiar que podemos resistir a essa onda de cinismo que invade tantos homens... 
${ }^{19}$ BENSUSAN, 2004a.

Rाт̇́c uเo: Resistir, va mos resistindo. Mas nã o me interessa ta nto essa erótica da resistência, da denúncia dosnossos desejos. Eu prefiro quando você faz seus discursos pela ação a firma tiva, pormais desejos de outros tipos, quando você confia que outrasimagens e outra sestórias vão me capturar e vão empalidecer a pornografia. Talvez seja possível dissolver a pedagogia pornográfica em um oceano de multipedagogias para os meus desejos... Mas quem vai prover tudo isso?

DWORKínCULO: Eu quero continuar tentand o começar. Tentando ver pessoas para além das suas partes. Tenho medo de Assimmesmo e de Deixaestar, mas noto também que eles não me erotizam - quero peitos, quero bundas, mas não quero me conformar. Não tenho desejo de beijare abraçar Assimmesmo e nem de dar mordidas em Deixa estar. Nem sequer quero enjaulá-los. Isso me faz perder um pouco da a nsiedade. Boto fé que eu posso fazerdiferente, pelo menos às vezes.

RITźculo: Às vezes perco a coragem, quero apenas uns desejos satisfeitos. Fica parecendo que sexo é uma a rapuca, é um atoleiro: meus desejos são também provação, a parte mais difícil de minha vida.

Dworkinculo: É. Mas parece que nessa parte difícil é que podemos ser um pouco mais livres. No meio dos meus desejos aparece todo tipo de coisa; na maioria das vezes aparece bem mirradinho, mas aparece. É nesses desejos mirradose incomuns que eu me agarro agora. Pelo menos enquanto eu tiver algum desejo de não mentir muito, de não esconder algumas partes de mim (e algumas tensões dosórgãos do meu corpo) debaixo do tapete.

15. Como os desejos se transformam? Eles seguramente são produtos de um agenciamento porque sã o susc eptíveis de ser coloniza d os. ${ }^{19}$ Outra s subjeti-vida des são possíveis apenas porque subjetividades são espaços para diferentes articulações de desejos e motivações. Porém meus desejos são diferentes a cada dia. Eles parecem estar convivendo em um ambiente ecológico próprio. Em cada uma das minhas ações feitas ou imaginadas, muitos desses itens estão presentes: como homúnculos que falam dentro de mim e, sempre, em minha primeira pessoa. Essa ecologia, no entanto, não está isola da da natureza e daspessoasa minha volta: meushomúnculos ta mbém respondem à história da minha espécie e interagem com as pessoas (e seus desejos) a minha volta. Os desejos se transformam porque as relações ecológ icas entre esses itens dentro de mim se transformam: há infecções, contá gios, disputas por hegemonias, relações predatórias, etc. 
${ }^{20}$ GUATTARI, 1989.
16. Proponho que concebamos os corpos como o ponto de confluência de três dinâmicas: a de nossa comunidade, a de nossas subjetividades e a do ambiente em que vivemos. Gostaria de pensar nos desejos a partir dessa confluência. O s corpos são o centro de um triângulo onde pensamos, nos adaptamos ao que está ao nosso redor e o transformamos - onde acontece nossa vida ecológica, como sugere Guattari. ${ }^{20} \mathrm{Guattari}$ apresenta a interação de três ecologias: a ecologia do ambiente, a ecologia das forças nas nossascomunida dese a ecologia das subjetividades. Cada corpo é constituíd o pela história - expressa no genoma - das opções políticas da comunidade que o produziu. A comunidade tem uma história biologizada. Cada corpo, depois, torna-se uma confluência de nós, do impacto emocional das pessoas a nossa volta e do ambiente ao nosso redor. Ações políticas agem sobre a biologia a nossa volta, a comunidade em torno de nós e os desejos que convivem na nossa subjetividade. Essas ações confluem no corpo que fazem para nós e no corpo que produzimos - em colaboração inseparável com o ambiente e a comunidade que encontramos - a partir do corpo que fizeram para nós. Os corpos são a confluência de nós, nossos próximos e a natureza que nos cerca. Por terem essas três pontas, os corpos são os a gentes de tra nsforma ção da s coisas - ca da corpo, com os afetos que produz e com as capacidades que abriga, deveria servisto como uma plataforma política.. Uma erótica que enxergue os corpos como uma tal confluência talvezpossa veroscorpos como posturas; cada corpo como um plata forma política - desejamososmesmos corpos porque temos (ou, talvez, somos direcionados a ter) pla ta formas polític as construída s em série. As pornog ra fias são disciplinas políticas que treinam nossos desejos para ter um impacto em série sobre nós e tudo o que nos cerca. Pensa ros corpos como pla ta formas permite que erotizemos as potencialidades de cada corpo atuar de maneira específica sobre aquilo que o circunda. A erótica, entendida assim, coincide com a política.

17. Se pudermos entender os corpos como plataformas políticas, temosuma resposta para como pode ser a política dos desejos: a política molecular que se confunde com a erótica. A política dos desejos pode ser a polític a do que tornamos público de nossas subjetivida des por meio de nossos corpos. Não é uma política em que cada pessoa tenha soberania completa - não temos soberania completa sobre o que se passa nos nossos corpos. Porém os corpos são plataformas de quem os carrega - quem carrega o corpo carrega também a 
${ }^{21}$ Esta é uma expressão linda de Audre Lorde: "Being women together was not enough. We were different. Being gay-girls together was not enough. We were different. Being Black together was not enough. We were different. Being Black women togetherwas notenough. We were different. Being Black dykes together was not enough We were different. It was a while before we came to realize thatour place was the very house of difference rather than the security of any one particular difference." (LORDE, 1983, p. 226).

22 KAY, 1998.

${ }^{23}$ A idéia de identidades construídasem uma política de diferenças é analisada de ma-neira interessante por Gloria ANDALZúA 1987. Noma ALARCÓN, 2002, por exemplo, explora como identida des de mulheres chicanas são construí-das. Essas construções sempre correm o risco de tomar o atalho do apelo a uma matriz de iden-tidade supostamente natural.

${ }^{24}$ Esta tese, posta a ssim, tem uma ressonância hegeliana. Hege entendia que nossa liberdade é determinada por onde a colocamos - liberdade é uma realização (um pouco ma is sobre isso em BENSUSAN, 2004a, p. 36) Hegel entende que a natureza em certa medida, não se resigna à passividade e mesmo os animais agem sobre tudo que Ihes é imposto, dentro dos limites dos seus recursos. No parágrafo $109 \mathrm{da}$ Fenomenologia do espírito, Hegel faz um curioso comentá rio: "[os a nima is] não ficam diante das coisas sensíveis como em si essentes, mas desesperando dessa realidade, e na plena certeza de seu nada as agarram sem mais e as consomem" (HEGEL, 1977 [1807]). Os recursos de cada espécie para transformar as coisas a sua volta se transformam, de um ponto de vista evolucionário, regulados pelo menos em parte pelo ambiente e com a história da espécie. bandeira que aparece com ele. A política dos corpos é talveza política das diferenças. É preciso escaparda ma triz que nos torna inteligível por causa das identidades sem nos tomar ininteligíveis. Nossa vida pessoal é talvez a casa das diferenças. ${ }^{21}$ As identidades decididas antes de que sejamos consulta dos não são ma is do que programas que nos to mam inteligíveis. Enossa vida pessoal à s vezespa rece um refúgio dessas identidades compulsórias: de perto, ninguém é só homem, só branco, só um elemento da classe média. E, no entanto, de perto somos homens, brancos, etc. Em Trumpet, Jackie Kay ${ }^{22}$ explora as conseqüências pessoais da nossa possibilidade de inventar identidades. Josephine se reinventa como um homem diante dos meios musica is, nos ambientes públicos, diante de seu filho. Seu filho, adotado, percorre uma jomada para compreender a distorção que seu pai promoveu a recusaruma identida de compulsória. Ele embarcou em uma trajetória de devirsaxofonista que o fez fugir de seu destino de gênero. Joss Moody, como ele fica sendo chamado, teria mentido ao seu filho - que não sabia de seu batismo como Josephine - apenas do ponto de vista das identidades natura is compulsórias. Se politizamos as identidades desde as diferenças, não deixamos que as identidades oficia is controlem o regime de verdade acerca de quem somos. A força das políticas da identidade está muitas vezes em a tribuir a uma natureza não-politizá vel a responsabilidade pelas nossas identidades (de homens, de brancos, etc.). Se nossa identidade (pessoal) deixa de estarpara a lém de toda a política, ta mbém quem somos vira uma questão de política das diferenças. ${ }^{23}$

18. A natureza muitas vezes é entendida como o ponto final de toda política - de toda capacidade de liberdade. Porém, a natureza, nesse sentido, pode ser a dia da ind efinidamente; podemostentarencontrar sentido para a tese de que as fronteiras do natural dependem de onde coloca mos nossa liberda de. ${ }^{24}$ Nossos corpos reg istra m a nossa história emocional e polític a e registram ta mbém o legado da história da nossa espécie. Em que sentido podemos dizer que essa história é uma história de escolhas políticas? Tento ensaiar uma maneira de entender a evolução das espécies como uma sucessão de escolhas políticas. Ali, no processo de evolução das espécies, há preferências que guiam a sobrevivência da espécie no seu ambiente, que guiam a transformação do ambiente pormeio da construção de nichos, que informam a escolha mesma pela sobrevivência. As espécies fazem política reagindo a o que o a mbiente, forma do também por outras espécies, apresenta. A ação responsável ou a ação 
25 Interessante comparar essas observações breves sobre a seleção a tra vés de nichos com a concepção de evolução recomendada por Richard LEWONTIN, 2000. Lewontin defende que genes, organismos e ambiente interagem constantemente para produzirem seqüências genétic as, outros organismos e ambientes modificados. Trata-se de uma tríplice hélice em que cada elemento não funciona sem os demais Trata-se de um modelo que se a ssemelha àquele das três ecologias entrelaçadas.

${ }^{26}$ HARAWAY, 1991. deliberada são, pensando assim, apenas uma das possibilidades de intervenção política. As escolhas são políticas, uma vezque cada uma delaspode serpensada, pornós pelo menos, como podendo serdiferentes. Instintos poderiam entã o serpensados como a herança da política da nossa espécie - nossa política de segurança (de garantias), nossa polític a de relações exteriores (com outras espécies) e domésticas (dentro de nossa espécie), nossa política de manutenção e fortificação da nossa espécie (eventualmente em detrimento de outras). Pelo menos nós vemos a política dos passos trilhados pela espécie. Nós a tribuímos, para entendermos o caminho que a espécie trilha ao invés de várias possibilidades alternativas, certas preferências. Pelo menos a tecnologia disponível para transformar nossa espécie é a mesma que dispúnhamos quando começamos a construir partes do ambiente onde evoluímos. Nichos são ambientes construídos pela nossa espécie onde desenvolvemos nossos comportamentos, nossos desejos e o pano de fundo para nossos comp ortamentos. Nic hos a fetam nossos genes que a fetam próximos indivíduos, que vão construir novos nic hos - o a mbiente promove a tra vés dosnic hos uma seleção política em que uma das ecologias de Guattari afeta as demais. ${ }^{25}$ A história dos nichos é também a história de quem os construiu; a ecologia que produza nossa espécie é ta mbém uma ecologia dos nossos desejos: daquilo que nos importa e daquilo que não nosimporta. A história de nossa espécie - ou se quisermos a pré-história de nossa política - foi moldada por uma seqüência de altemativas guiadas, por exemplo, pelo apego à segurança, pelo apelo à sobrevivência, pelo a pego à previsibilidade. Nesses ca minhos podemos enxergar - e reexaminar - as escolhas polític asque moldaram nossa espécie. (Uma imagem assim da natureza está em grande medida em consonância com o modo como feminismos como o de Donna Haraway ${ }^{26}$ pensam nossa capacidade de intervir sobre nossos corpos e nossa biologia.)

19. Diante dessas observações podemos sentir a tentação de perguntar se houve escolhas e política na história da nossa espécie. Nós, desde onde estamosagora, podemos espreitar essas escolhas e reconhecê-las como escolhas - e como escolhas políticas acerca dos desejos. Pelo menos no seguinte sentido: nós concebemos que poderia ser diferente. Uma resposta: concebemos que poderia ser diferente, sim, mas a natureza obrigou nossos antepassados a fazerem (e desejarem) aquilo que eles fizeram (e desejaram). 0 desejo era, naquele momento, natural. Onde começa a natureza termina a política? Ou 
antes, onde termina a natureza? Como pode a natureza, em algum ponto, deixar de atuar? Mas a natureza deixou diferentes heranças em nossos corpos. Os desejos natura is talvez tenham sido muitos, escolhidos em diferentes circunstâncias por diferentes a mbientes conting entes e produzidos. As heranças natura is e as heranças de nossas respostas à natureza parecem se confundir desde o início. Nossos corpos são pla ta forma polític a porque são na tura is.

20. Nossos corpos e nosso erotismo - como nossas plataformaspolític as - são a confluência dastrês ec ologias. Talvez o erotismo seja o equilíbrio delica do e precário entre a ponta da península, nossa comunidade e as forças natura is que estão pelo nosso a mbiente. Nosso erotismo é o reflexo de nossa política. E, em algum sentido, nossa política é particular; ela não pode ser determinada meramente pelo nosso ambiente ou pelos grupos de identidade de que participamos. Nossa política e nossa erótica são também função de nossas afinidades: o que nós fazemos na posição política e erótica em que nos colocaram. Penso que o erótico é radicalmente particular. 0 erótico é uma confluência de ecologias porque é nossa maneira de construir nossa própria oikos entre nossos desejos e temores, nossas comunida des e nosso a mbiente. É particular de cada pessoa como um lar, é particular de cada circunstância, é particular de cada história de vida. $\mathrm{E}$, no entanto, o pessoal (que é pa rticular) é político. (Não há lares que são refúgio de toda política - isso a inda não quer dizer que não há lares.)

21. Consideremosa política da motivação para um estupro. 0 estupro é parte da militância política em favor da supremacia masculina. 0 estupro milita ma is ou menos assim: o desejo masculino é uma força da natureza, é um elemento de motivação inteiramente independente de todo o resto das coisas que os homens pensam, temem ou sentem. Portanto, as mulheres devem se curvar a ele, ou seja, devem contomá-lo, como fazemoscom um penha sco que não podemos mover. A política da masculinidade é a polític a da sa cra liza ção do desejo ma sc ulino; a gimos como se o desejo estivesse a cima de qua lquer liberdade. Por que exatamente sacralizamos esse desejo? Para nós, homens, essa estrutura preexistente de desejo garante uma quota de poder em nossas mãos porque, de acordo com essa estrutura, nós desejamos dominar, submeter, possuir - a estrutura faz nossa vulnerabilidade esva ecer: somos fortes, somos homens, a estrutura preexistente dos desejos; este deus ex-machina para o qual reza mos quando estup ra mos ou somos coniventes com o estupro - ou, porvezes, ficamos 
${ }^{27}$ Gen VAUG HAM, 1997, defende que a masculinização, e, portanto, a diferença entre os gêneros, é uma diferença primariamente econômica. Ela entende a economia como a maneira como satisfazemos nossa snecessida des (por a brigo, comida, a feto, atenç ão, etc.). Os homens são ensinados a pertencer primariamente a um esquema de economia de troca as mulheres a uma economia da dádiva.

28 SEG ATO, 2003

${ }^{29}$ RUBIN, 1975. excitados com ele - está do nosso lado. Pouco importa quanto desejo esteja presente - importa mais o caráter incontrolável: importa que este pareça ser o desejo. Essas ações, e conivências, endossam um programa político (o programa da masculinidade) que pensamos que vai nos trazer algum benefício. Ou então que pensamos que devemos endossar porque, se não endossamos, nos toma mos desprezíveis a os nossos olhos. Para os homens parece que o programa masculino é endossa do por uma mistura de conveniência e de obrigação. Quando os homens, como um grupo, impõem que seus membros sejam capazes de estuprar - que seus corpos sejam capazes de levara cabo uma tal ação é uma mostra de fidelidade ao g rupo na pla taforma polític a do homem -, estão a firmando um conjunto de práticas que ga ra nte que as mulheres terão de contomar penhascos: as mulheres terão de encontrar um modo de conviver com a lealdade de honra dos homens.

22. Os homens atuam como um grupo quando se reconhecem em um conjunto de práticas de desejo. Os homens pertencem ao grupo quando obtêm algo das mulheres: a masculinização é o processo de aprender a ocuparum espaço emocional, econômico e político junto às mulheres. As pessoas são masculiniza das aprendendo a ter uma relação com as mulheres que coloca os afetos em um regime de troca, ${ }^{27}$ que demanda uma dose de a tenção e afeto, que considera normal ter certas priorida des (e que as mulheres tenha m certas obrigações; por exemplo, a de serem as principa is responsá veis pelas atividades da prole). Rita Laura Segato ${ }^{28}$ a credita que os homens cobram um tributo das mulheres para ga rantir sua inclusão no grupo masculino. (Gayle Rubin ${ }^{29}$ entende que o trá fic o de mulheres entre clãs funciona como uma protomercantiliza ção das mulheres, o tráfico de mulheres depende de um cercamento que as coloca dentro do espaço que é propriedade dos homens.) Esse tributo é o símbolo da dominação e é pago em termos de atenção, a feto, controle sexual e serviços doméstic os. Um homem é visto como homem se há mulheres prestando serviços de alguma natureza a ele. A masculinidade é um grau outorgado por um grupo àqueles que a tua $m$ de acordo com as normas que regem o reconhecimento dos homens. A a prendiza gem dessa dita na tureza, é c la ro, não é sempre fácil.

23. Desde quando há estupro? O estupro é a origem do patriarcado? Devemos procurar a história pré-estupro? Cynthia Eller ${ }^{30}$ argumenta que não precisamos de uma 
31 MORGAN, 1972

32 Atua is pesquisa s com chim panzéspa recem mostrarque eles fa zem, sim, guerra entre tribos com mortes. Desconheço se eles, nessas circunstâncias, respondem ao sinal de rendição. De to da maneira, importa mais aqui a estrutura das explic ações de Ela ine Morgan.

${ }^{33}$ HYDE, 1983 história pré-patria rcal para criar um futuro feminista. Ela ine Morgan ${ }^{31}$ procura explicar o estupro e a incapacidade humana de conter genocídios na própria espécie. Ela diz que nós somos a única espécie de primata que copula com um conta to ventral e a única espécie que é capazde matar um membro da própria espécie em qualquer circunstância mesmo que quem esteja para ser morto dê um sinal de que está se rendendo. ${ }^{32}$ Nós não temos a capacidade de respondera um sinal que signifique "c hega, eu me rendo", que, na maioria dos primatas, acontece por meio da exposição da região do ventre. Morgan procura explicar essas duas característic as humanas por meio de um relato evolucionista de que alguns homens foram premiados por sua incapacidade de responder ao sinal de rend ição - que fa zia os dema is fic a rem pa ralisa dos diante de uma mulher que expunha a barriga - com um intercurso mais prazeroso e mais produtivo (mais reprodutivo). Ou seja, os estupradores (potencia is) foram selecionados pela evolução da espécie. A efetividade da reprodução pela cópula fezcom que homens insensíveis à rendição fossem selecionados. Está nos nossos genes a herança de nossa sbiopolític as ta na tófila spassa das - nossa natureza. E, contudo, a imagem que surge de sugestões como a de Morgan é que a nossa natureza não é o fim de toda demanda de explicação: nossa capacidade de sermos violentos é uma evolução contingente da espécie que nos fez desaprender a entender sina is de rendição. Aí conectamos a rendição a prazer. A evolução da masculinidade, entã 0 , produziu esse gênero tana tófilo. Podemos ouvir um relato como o de Morgan como um rela to da evolução da nossa espécie que co-evoluiu com uma ecologia dos desejos masculinos; isto é, se a evolução da espécie se mistura com a evolução dos desejos da espécie, a história política dos nossos desejos pode ser traçada em um relato como o de Morgan.

24. A política da preservação da espécie a qualquer custo parece orientar o relato de Morgan. A violência é muitas vezes um produto de um garga lo na circula ção dos bens e serviços que nec essita mos: com a cesso irrestrito aos meios de produção, aos meios de a utopreservação e aos meios de conforto emocional haveria menos violência. Parece que os meios de preservação dos próprios genes são escassos no relato de Morgan: se essa escassez é natural, a conexão entre violência e sexo entre humanos é natural. A escassez, no entanto, pode ser uma produção dos nossos desejos e das formas de vida que se produzem com eles: das ecologias que produzimos com nossas práticas. Lewis Hyde ${ }^{33}$ contrapõe a dádiva à propriedade 
${ }^{34}$ Um personagem do filme The oppposite of sex, de Dan Roos (1998), define uma relação amorosa em termos que parecem, nesse contexto, bastante lúcidas desde dentro das nossas relações de escassez erótica. Ele diz para sua nova parceira: "To me, sex is not about procreation norabout recreation, it's aboutconcentration. In a room full of people you look at me first, and I do likewise" (Para mim, sexo não é procriação e nem recreação, é concentração. Em uma sala cheia de gente, você olha para mim primeiro, e eu faço o mesmo".

35 BENSUSAN, 2004a, 34

${ }^{36}$ Alice Walker, na sua obra-prima sobre a finidades em conflito (Advancing Luna - and Ida B. Wells, em WALKER 1971), torna nítida essa dimensão da política do estup ro. Ela considera rápida, mas incisivamente a tivistas do movimento negro nos EUA como Eldridge Cleaver e LeRoi Jones que falavam dos estupradores revolucionários e eram capazes de recomendar aos homens negros que estuprassem as garotas brancas, estuprassem seus pais. No texto de Walker muitas dimensões do estupro inter-racial - muitas delas reminiscentes do tráfico de mulheres - são consideradas do ponto de vista da confiança de uma mulher negra, entrelaçada entre duas solidariedades (cf. BENSUSAN, 2004b)
- esta faz o valor a cumula do estragar porque esta gna do e entende a dádiva como promotora de riqueza em todo o círculo que está envolvido entre quem ganha e quem recebe presentes. A a cumulação, produto da impressão de escassez (ou, se quisermos, de ansiedade produzida pelo medo da escassez), retira os bens de circulação e os impede de criarriqueza. A a cumulação é feita de privação. A política da preservação dos meus genes prefigura a predicação de filhas e filhos (ou crianças) como meus. Nossas práticas de preservação são práticas de preservação de alguma coisa. O que queremos preservar de nós e por que queremos preservar o que queremos preservar? Nossa noção do que é próprio de nós é um indício de como se orienta nossa política. Em contraste, espaços afetivos podem ser vistos como espaços de dádiva, espaços onde não preponderam as relações de prop riedade. Essesespaços, e osmovimentos dentro deles, são terrenos constantemente redefinidos, reavaliados, renegociados.

25. Uma possível a lternativa à a ssociação entre desejo de um lado e posse, controle, submissão do outro é entendê-lo no âmbito da dádiva em oposição a o âmbito da propriedade: pensar que amar é deixar livre, desejar como dá diva, entendero desejo como um bem abundante que provoca mais desejo e não como uma mercadoria escassa que temos de preservar. Se o desejo é uma dádiva e desejar não é possuir, os bens eróticos não perdem a vitalidade que ganham quando circulam pela comunidade. O desejo entendido como produtivo não precisa ser controlado e nem possuído; o desejo escasso demanda controle e concentração. ${ }^{34} \mathrm{O}$ regime da escassez erótica é o regime que faz com que queiramos garantias para desejar e sermos objetos de desejo: é o regime que toma próximos o desejo e a posse. Esse diagnóstico das relações de posse pode fazer o ciúme ter a mesma origem da acumulação: o terror da escassez. Em Observações sobre a libido colonizada ${ }^{35}$ eu trato de um regime de escassez da afirmação. Talvez possamos falar de uma maneira de viver que torna o que é erótico escasso. 0 regime de circulação de erotismo produz escassez promovendo algum cercamento de pessoas, ou seja, determinando que pessoas são propriedade de outras pessoas. 0 estupro foi por muito tempo considera do como uma violência contra a propriedade doshomens - e talvez tenha muitas vezes sido motivado como um assalto a um bem alheio. ${ }^{36}$ Outras vezes, 0 desejo de posse é o mais preponderante: ser um homem é tomar posse. Sem o gargalo, o prazer poderia estar sempre consentido. Que 
${ }^{38}$ A chora é freqüentemente pensada como aquilo que se opõe e precede a qualquer determinação, a qua lquer forma e, portanto, a qualquerconc eito. Butler entende que, para Kristeva, acessar essa ausência de determinação é encontrar um feminino para além do esforço falogocêntrico de determinar. Para Irigaray, a idéia mesma de uma chora, de algo que precede a determinação e assim fic a determinado depois da determinação, é guia da poruma erótica da entra da e da contenção: essa erótica guia a maneira como pensamos na matéria - inerte passiva, ind etermina da, disforme - em contraposição à forma. A dualidade, ela suspeita, é fruto de uma maneira de pensarque se orienta (eroticamente) por dualidades como atividade e passividade. estruturas políticas seriam necessá rias para que o estup ro não fosse mais possível?

26. É cômodo e tranqüilizante pensar na natureza como um rincão de incontomáveis dentro de nós; uma idéia que é prima daquela que nos faz perguntar quem nasceu primeiro, a natureza ou a pomografia. Claro que uma maneira de exorciza ra possibilidade de que a natureza seja nosso álibi é enfatizar que a pomografia construiu o nosso senso do que é natural. É como se recuássemos de um apelo central à natureza em direção a uma maneira de nos entender que é por completo alheia à natureza, em direção a uma concepção segundo a qual ela lava suas mãose nós somos ind iferentes a ela. Como a na tureza pode entrar nas explic ações de nossa s políticas (de nossos desejos) sem aparecer como o rincão de incontomáveis onde toda política - e todo desejo propriamente nosso termina? Há o risco de nos encaminharmos para uma physiphobia, um desprezo à natureza segundo o qual a na tureza não tem papel a lgum sobre nossa spráticas. Judith Butler $^{37}$ diagnostica em certas formas de pensar gêneros uma condição similar que ela apelida de somatophobia: o desprezo a qualquer uso do corpo nos nossos discursos sobre gênero, como se o corpo não fizesse ele mesmo diferença alguma. Quando rejeitamos a idéia de que a nossa imagem da pomografia surge da natureza para adotar que a nossa imagem da natureza surge da pomografia, podemos nos incomodar com a situação em que a natureza não tem qualquer papel sobre nós; como o incômodo que podemos experimentar quando desconectamos nossa sexualidade do nosso corpo. Butler entã o promove, com um recurso à discussã o entre Iriga ray e Kristeva sobre a chora, ${ }^{38}$ um diagnóstico de que nos a pressamos a perguntar pela materialidade ou a corporalidade) do sexo antes de perguntar pela sexualidade da matéria (ou de um corpo que preceda nossas práticas sexuais). Nossa maneira de pensar na matéria - e, eu diria, na natureza - é informada por uma erótica, por uma sexualidade de acordo com a qual controle e descontrole (o irremediável, o incontrolá vel, o lócus da necessidade pura) estão separados em uma dualidade. A natureza e o que, sim, é contomável não precisam estar em quartos separados: nós, em nossa a tuação sobre as ecologias, produzimos aquilo que a parece como incontomá vel. A imagem que emerge para mim aqui é de uma interação constante com muitos elementos da natureza. A política dessa interação é também a erótica que orienta nosso pensamento. Não é uma política de escolhas decisivas porque a política em 
${ }^{39}$ Ver, por exemplo, José GIL, 1997. Ali Gil reflete sobre a dificuldade de separarcomosde discursose códigos sobre corpos. Que obteríamos com uma separação assim?
${ }^{40}$ As seções 27-33 são elaborações a partir do texto que apresentei em outubro de 2005 na Sophia +, Braślia, em um cic lo associado à exposição aartesupranaturaldosjardins de Gise Carriconde Azevedo. Agradeço às gentes da Sophia + e à Gisel pela oportunidade de pensarna metáfora dos corpos como jardins. nossa própria casa é também a ecologia do nosso endereço e do ambiente que deixa a casa de pé. A natureza pode ficar diluída na política que promovemos como a pomografia. Ou seja, não precisamos adotarnem a tese de que a natureza fica inerte e sem influência sobre nossas práticas sexua is (que a pomografia a precede) e nem que ela seja o lócus daquilo que nós não transformamos (que ela promove a pornografia), mas podemos pensar a natureza como afetando o conjunto dos nossos pensa mentos sempre. Podemos pensar no que é natural em nós como resultante de interações das ecologias.

27. O corpo, um rincão da natureza que às vezes é chamado de signific ante-zero, ${ }^{39}$ não parece ter nenhuma propriedade própria, intrínseca. Ele é sempre uma confluência. Em certo sentido, nosso corpo é natural não como uma floresta, mas como um jardim. Proponho uma leitura - oblíqua e retorcida - da punchline de Voltaire em Candide, uma leitura decididamente a contra pelo do motto il faut cultiver notre jardin. Nosso jardim é nosso corpo. Penso que nosso corpo é natural não como uma terra incógnita. Nosso corpo é uma das primeiras coisas que apontamos quando queremos indicar que coisas são nossas (se bem que às vezes ele ta mbém é a ponta do para indicaro que nós somos). Nosso corpo é o que pensamos também quando falamos do nosso quinhão de natureza. E não se trata de algo que possa ser alheio a nós - não pode ser completamente confiscado, mas pode ser em algum sentido abandonado, um corpo inteiramente descontrolado, sem dono. o ônus do abandono pode ser aqui de três jeitos: pode ser um corpo que não responde, pode ser um corpo que não responde a alguém, pode ser um corpo que não responde a um sujeito que assujeita aquilo que consideramosque pode estar sujeito a um sujeito no corpo de um sujeito. Assujeitar é muitas vezes ta mbém metáfora para a propria r. Oscorpos sã o metá fora súteis pa ra falar de propriedade: nossas proprieda des sã o nossa s c omo nossos corpos são nossos; nossos corpos são exemplos seguros do uso dos pronomes possessivos. Fic a parecendo que o sujeito pode ficar desapropriado - como o corpo, ou os jardins, podem ficarabandonados. ${ }^{40}$

28. A metáfora da propriedade tem problemas: a proprieda de do nosso corpo não pode ser desapropria da e apropriada poroutro dono; a propriedade do nosso corpo parece sero que fazcom que possamos ser reconhecidos como sujeitos - é parte do que, de alguma maneira, temos 
que assujeitar para sermos sujeitos. Dificilmente encontramos sujeitos que não a ssujeitam nenhum corpo e nenhuma porção da natureza. Parece que nosso corpo está mais intimamente ligado a nós, como um jardim compulsoriamente nosso. (Possivelmente não podemos pensar em corpos que não sejam corpos de a lguém, como não podemos pensar em estados menta is - desejos, pensamentos, temores - que não sejam de alguém.) Então às vezes parece que nosso corpo somos nós, ou parte de nós. Oscilamos entre pensar que nosso corpo é parte do que é nós e pensar que ele é parte do que é nosso (este corpo sou eu ou é meu). Corpos, partes de nós ou partes nossas, muitas vezes são também vistos como vitrines de nós. Mostra-me teu corpo e eu te direi quem és. Aqui queremos dizer mostra-me o jardim que cuidas e eu te direi quem és, mas também mostra-me o que cresce (e como cresce) no teu jardim que eu te direi quem és. 0 corpo, se não for o todo, será então a parte do todo que tem uma potência metonímica. Podemos procurar nossos afetos, e a história de produção e repressão deles, nas habilidades dos nossos músculos, nas couraça s em torno de nossas a rticulações, nas tensões que acumula mos em certas áreas.

29. Minha terapeuta bioenergética me conta que meus braços se enc urta ram por eu não ter podido a vançar e segurar o que eu queria. A história dos meus desejos, e de sua realização, ficou escrita no meu corpo. Que parte do mundo é esta que fica sendo meu biógrafo nãoa utoriza do? Meu corpo, como biógrafo, tem a vantagem importante de ter esta do onde quer que eu estive: a forma dos meus músculos registra meus movimentos, o estado dos meus nervos registra minhas a preensões, o esta do do meu coração registra meus medos. Pelo menos, este biógrafo somático é um quinhão da natureza que esteve sempre comigo.

30. Parece que meu biógrafo fez ma is do que estar presente; ele fezcom que eu fizesse o que eu fiz-- os abraços que dei, os bilhetes desesperados que esc revi, as fugas que corri. Ainda, parece que ele é mais que testemunha e instrumento: ele é também minha cômoda permanente, minha casca de caracol; onde eu sempre estou. É meu bióg rafo não-a utoriza do que é meu auto-b ió gra fo a utoriza do. Minha terapeuta, possivelmente, enxerga meu corpo desde fora, como quem vê um jardim pela grade da rua. Meu corpo é visto como um elemento da natureza; quero dizero seguinte: ele é visto a partir de um ponto de vista de terceira pessoa e não com a minha voz sintonizada com minha 
${ }^{41}$ MORAN, 2001.

${ }^{42}$ Cf. BENSUSAN e Manuel de PINEDO, 2006 (primeira) pessoa. E meu corpo pode ser visto assim; é por isso que ele é uma (auto-)biografia e, ao mesmo tempo, não autoriza da. Sim, eu nã o leio tud o o que minha tera peuta - ou qualquer um de vocês que esteja m em algum sentido do lado de fora do meu corpo - lê no meu próprio corpo. Há coisas sobre meu corpo que você sabe e eu não sei, há coisas que ninguém sabe: ainda assim o corpo é meu ou eu. Ma is do que isso, eu também posso a prender a ler meu bióg ra fo não-a utoriza do e, mesmo, concordarcom ele sobre mim, ainda que eu nunca escreveria as palavras (ou os movimentos de ombros) que ele escreveu. Ou seja, eu posso aprender a ver meu corpo também desde fora, também como parte da natureza; desde um ponto de vista de terceira pessoa. Posso olhar o jardim como um troço da natureza, como olho uma floresta - mas este não é o olho que eu uso quando me ponho a jardinar.

31. Parece que há uma diferença entre me vercomo os outros podem me vere me vercomo eu me vejo. Richard Mora $n^{41}$ tem feito esforços para mostrar que uma distinção assim não quer dizer que eu possa ver alguma coisa em mim que uma terceira pessoa (ou uma segunda pessoa, pois isso pode ser importante) não pode ver. Ele também tenta mostrar que isso não quer dizer que minha visão de primeira pessoa vê mais longe, introspecta com mais precisão. No meu modelo da esfera dos desejos, minha capacidade de me darconta de meus desejos é apenas um acesso a eles - não traz nenhuma incorrigibilidade e nenhuma a utoridade privilegia da assim como o acesso de primeira pessoa não determina o conteúdo de minhas crenças. ${ }^{42}$ Quem jardina não vê ou sabe nada que outras pessoas não possam saber sobre o jardim e nem vê ou sabe de uma maneira necessariamente ma is acurada. $E$, no entanto, a voz de primeira pessoa é diferente de qualqueroutra. Tento pensa rassim sobre meu corpo: desde dentro dele o enxergo de uma maneira diferente da maneira que vocês aí de fora o enxergam; não que haja uma parte do corpo que só eu posso ver e nem que de onde eu estou se veja melhor. Ainda assim, se eu quero conhecer meu corpo, tenho que conhecer o que vocês vêem e o que eu vejo. Parece que preciso de um caleidoscópio de lunetas - e de pontos de vista - para que eu possa enxergar alguma terra firme. Nossos corpos têm a voz dos corpos - a voz da natureza que pode ser descrita desde fora, alheia a qualquer possibilidade de introspecção - mas tem a voz do nosso - ele está sujeito a o mundo estando sujeito a nós. Se o corpo fala, ele fala então nessa polifonia. 
32. Pode haverconflito de vozes; posso dizeralguma coisa que meu corpo nega, posso desejar alguma coisa que meu corpo não deseja. Podemos a tribuir crenças e desejosa nós a partirde uma perspec tiva de terc eira pessoa sobre nós mesmos (como se nós nosolhássemos desde fora). É o caleidoscópio de lunetas: como posso determinar a verdade dos relatos do (auto-)biógrafo somático nãoautoriza do? Não posso a pelar a penas para a minha voz (o que eu penso sobre meus desejos, meus medos, minhas convicções ou meu corpo): isso seria determinar uma priorida de da minha luneta de primeira pessoa. Talvez valha considerar que a verdade não está em parte alguma, não há uma morada da verdade onde ela fica esperando que nós a espiemos. Então nem o nosso corpo é a morada da verdade-sobre-nós. Lunetas de terc eira pessoa podem estar enganadas sobre nós, elas podem estar vendo mal o que está no nosso como, lendo mal as entrelinhas composta pelo biógrafo. Porém, meu corpo só pode escrever a autobiografia com palavras que entendemos. Moran entende que 0 a utoc onhecimento não deve seguiro modelo daquilo que conhecemos por contemplação; nossas reflexões sobre nós afetam aquilo que nós somos, ele diz: "uma pessoa tem sempre um papel na formulação daquilo que ela pensa ou sente". ${ }^{43}$ Meu corpo conta coisas para minha terapeuta que eventualmente vão se expor a o meu crivo - meu crivo é o que pode tomar a biografia nãoautoriza da parte da minha vida. Meu crivo, que é feito com a matéria-prima de tudo o que as pessoas e as coisas a minha volta colocaram em mim, é o que constitui minha voz de primeira pessoa. 0 crivo é meu porque eu ativamente, com meus pensamentos, cuido dele. Meu crivo atua de alguma forma sobre meus desejos - é a primeira pessoa que me conta sobre o que eu quero. A transformação dos meus desejos requer um caleid oscópio de imagens do meu corpo e do que ele é capaz. A voz da pomografia tomou-se a minha voz. Mas a minha voz de primeira pessoa é sempre permeável por vozes de fora - ainda que não possa ser substituída por elas.

33. Além de biógrafo e instrumento, meu corpo parece abrigar ta mbém as minhas potencia lidades; talvez minhas potencia lida des seja $m$ as potencia lidades do meu corpo. Por exemplo, as minhas potencialidades afetivas estão elas também inscritas no meu corpo: o que me assusta, o que me excita, o que me convence, o que me instiga. Spinoza tinha uma concepção dos a fetos segundo a qual eles podem ser examina dos pelos seus efeitos nos nossos corpos: por nos deixar mais ou menos ativos. As capacidades do nosso corpo não são a lheias a nossa vida 
${ }^{44}$ DELEUZE, 1977. a fetiva: nossa vida a fetiva se espelha nas capacidades do corpo. E então podemos perguntar o que pode um corpo - e corpos, com suas diferentes histórias a fetivas, podem sempre coisas diferentes. Gilles Deleuze, ${ }^{44}$ a partir de Spinoza, entende que os poderes instituídos a tuam sobre os corpos menos para reprimi-los do que para angustiálos, para diminuírem sua capacida de de ação. Ospoderes produzem corpos, como produzem desejos, como produzem maneiras de pensar. Um corpo, insiste Deleuze, tem potencialidades para além daquelas que o faz um orga nismo funcional: a lém de funcionar, ele a ge. Um ja rd im tem potencialidades: o que pode crescer naquela terra, que capacidades de afetar quem o visita ele abriga (de produzir serenidade, inquietação, vivacidade, júbilo ou melancolia)? Nossos corpos, porque são também natura is e como tudo o mais, não são jamais completamente a ssujeita dos por nós. Eles estão conectados a nós e jama is separados de tudo o que os rodeia.

34. Os corpos sã o significantes-zero talvez porque são o ponto de encontro do ambiente, das dinâmicas de poder e das subjetividades - as três em interação ecológica. Subjetividades são controladas pelas capacidades natura is e pelas pressões de poder que produzem, mantêm e reforçam nossos afetos (cultivam, podam ou cortam pela raiz o que pode germinar). Nossas comunidades são reguladas pelas capacidades natura is e pelas subjetividades que a compõem - pelos recursos natura is e pelas maneiras de pensare sentir diante desses recursos e sua disponibilidade. A natureza, que também não é tão Grande Outra, é influenciada por como as subjetividades se expandem ou contraem (os afetos que proporcionam o consumo, a privação ou o esbanjamento) e pelas comunidades que criam nichos que afetam as espécies a serem selecionadas e mantidas. Os nichos nossa s cida des, nossa s pla nta ções e terrenos de pa sto reio, nossos jardins, nossos hábitos com respeito a o nosso corpo - são ambientes construídos pela nossa espécie onde desenvolvemos nossos comportamentos, nossos desejos e o pano de fundo para nossos comportamentos. Nichos a fetam nossos genes que afetam próximos ind ivíduos, que vão construir novos nic hos. A história dos nic hos é ta mbém a história de quem os construiu; a ecologia que produz a nossa espécie é também uma ecologia dosnossos desejos: daquilo que nos importa e daquilo que não nos importa. Os corpos registram a história e as histórias possíveis.

35. Os corpos são também a confluência do que é públic o e do que é privado. Eles são nosso espaço público, 
nossa imagem pública. O pessoal é político, nossa vida emocional, nossas inclinações, nossas imagens de quem somos. Os termos que usamos para descrever nossas a tivida des - os termos, as concordâncias, as construções gramaticais - estão permeados da estrutura política de nossa comunidade. Mas o que fazer? Não parece que possamos denunciar essa estrutura de poder como uma escolha errada - votemos antipatriarcal nas próximas eleições. Não se trata de uma escolha, mas antes da natureza mesma das escolhas: a mic roestrutura do nosso desejo. Trata-se da política que envolve todos os nossos atos porque é a política da nossa vida mental (e, por isso mesmo, a polític a dosnossos corpos). Aqui a denúncia não parece ser suficiente. Subverter essa ordem de desejos requer outros desejos - o desejo de subverter, ma is forte do que o desejo de estar aceito e mais forte que todos os desejos produzid os pelo desejo de esta ra c eito. A subversã o parece requerer outros corpos. E há muitos corpos - muitas plataformas políticas - subversivas.

36. A idéia de que podemos separar instintos da espécie de desejos pessoais é um resquício da idéia de que podemos separar o corpo que herdamos da nossa espécie (do nosso genoma) do corpo que adquirimos ao longo das nossas escolhas (e imposições das nossas comunidades). Não podemos: temos um só corpo. Temos instintos apenas no sentido de que nosso corpo responde também ao seu ambiente que, por sua vez, responde ta mbém à s escolhas dos antepassa dos. Não há uma parte do nosso corpo (ou de nossas disposições para agir) que seja ma is natural do que qualquer outra: os instintos, e seus conteúdos, estão misturados por entre as ecologias dos nossos desejos. Não há por que supor que os instintos tenham um conteúdo próprio, ma is básico, ma is elementar - ma is natural. Nossos instintos podem ser tã o complexos e tão natura is como o resto de nós. Nosso corpo - com sua história pessoal, coletiva e biológica - é o repositório ou a origem dosnossos desejos: nossa plataforma política. Assim, no modelo que proponho para entendermos os desejos, os instintos não têm um conteúdo fixo e alheio a nossa história e a nossa subjetividade. Também não têm uma autonomia em relação à s pessoas a nossa volta. Masnem por isso estamos a utoriza dos a desconsiderar a influência dos instintos sobre nossos desejos. A história de nossa espécie está inscrita no nosso genoma que, no entanto, pode adquirir diferentes conteúdos em associação a diferentes ecologias subjetivas e diferentes ambientes socia is. Não há nenhum dos itens na ecologia dos nossos desejos que seja um mero reflexo dos nossos instintos. E, no 
entanto, respondemos a os nossos instintos porque não há nenhum item na ecologia dos nossos desejos que seja independente dos nossos instintos. Os desejos são viáveis se eles podem acontecer em um corpo que foi formado pela história da espécie. A na tureza, que ta mbém não está a lheia à soberania da nossa espécie, tem um impacto sobre nossos desejos, se bem que nã o possa mos isola ro conteúdo desse impacto em nenhum momento. Nossos desejos não podem ser entendidos fora do ambiente em que acontecem - ambiente onde há outros de nossos desejos, nossas crenças, nossostemores, etc. (como uma sociedade de homúnculos de que Ritzículo e Dworkínculo, na seção 14 a cima, são exemplos). Esse a mbiente dos nossos desejos recebe o impacto de todos os lados da confluência de ecologias que é nossos corpos.

37. Esse modelo, holista e ecológico, da esfera dos desejos é inspirado pela maneira como Donald Davidson a rticulou a relação entre pensamentos e mundo a partir da conexão entre verdade e inteligibilidade. ${ }^{45}$ Ali, nossas crenças respondem ao mundo, uma vez que elas são também a base da inteligibilida de de um confronto entre pensamento e mundo. Aqui, nossos desejos estão a riculados com nossos instintos, uma vez que só em um ambiente de desejos algum instinto pode ter conteúdo e ter alguma força na determinação de nossas ações. Davidson consegue tomar desnecessário o apelo a um ponto onde nossos pensamentos e o mundo se encontram - um ponto onde eles poderiam ser confrontados. Esse modelo também toma desnecessário um ponto em que a na tureza e nossos desejos se encontram - o ponto onde os instintos teriam alguma a utonomia. Não há entre os nossos desejos nenhum que é mais natural - e, a o mesmo tempo, não precisamos exorcizar o caráter natural dos nossos desejos: eles respondem à natureza.

38. O modelo é compatível com a idéia de que o pessoal é político sem deixarde ter uma autonomia própria - o pessoal é pessoal a lém de ser político, como nas penínsulas de Oz (cf. seção 3 acima). Trata-se de um modelo ecológico em que a esfera pessoal, a natureza e as a rticulações históricas da sociedade a nossa volta são pensadas não como autônomas e regidas por princípios próprios, mas antes como vasos comunicantes por meio de pressões ecológicas que a parecem em muitas formas de políticas do desejo. Assim, por exemplo, os discursos feministas sobre a pomografia entram em conta to com os desejos masculinos e uma resultante ecológica aparece em diferentes corpos (em diferentes momentos). Essa 
${ }^{46} \mathrm{G}$ islene Aparecida dos SANTOS, 2004, p. 16-19, conta a história de Lila, mulher negra que tem dificuldade em reconhecer qualquer traço de solidariedade vinda de uma outra mulher negra, Rita, milita nte anti-racista. Ela conta que suas amigas brancas lhe diziam: "porque ela seria diferente das outras mulheres por ser militante? Ela discute o racismo e não a vida dela". É como se a vida de Rita, o ímpeto que move seus desejos partic ula res, estivesse alheio à causa em que ela milita e tivesse vida própria, decerto mais forte do que podemos esperar que sejam as convic ções que a faça militar. E, no entanto, Lila pensa que Rita, ao se comportar do modo como se comporta, reforça e coloca em evidência precisamente a matriz de comporta mento que ela se mobiliza para denunciar. Ao discutir o racismo (ou a supremacia heterossexua e masculina) e não discutir sua vida, Rita estaria permitindo que a vida pessoal escapasse entre os dedos para fora de qualquer arena política. resultante faz dos corpos arenas políticas e ao mesmo tempo palanques que podem influir na ecologia de subjetividades de outras pessoas. A natureza deixa de ser entendida como um espaço a lheio à polític a e passa a ser uma a rena e um reflexo de nossaspolíticas. Nossa soberania polític a não acaba onde começam os ambientes na tura is; ta mbém eles respondem à intervenção de nossos desejos, ta mbém eles são permea dos de ecologia natural (cf. seção 18 acima e, ali, nota 25). A política que se reflete no ambiente natural (e social) a nossa volta, contudo, freqüentemente não é a política que permite que orga nizemos passeatas, partidos polític os ou eleições. É antes, conforme seção 17 acima, uma política de diferenças. Trata-se da política da península de $\mathrm{Oz}$, que reflete sobre nossos corpos e por isso não deixa nenhum espaço dentro de nós alheio. ${ }^{46}$

39. Gostaria de esclarecer um pouco mais a importância da politização nesse modelo; especialmente tendo em vista a coincidência entre política e erótica no corpo (apontada na seção 16). A politização promove o contágio de desejos por outros desejos - anseios de solidariedade ou justiça interagem, por exemplo, com o senso de honra associado à masculinidade. As relações ecológicas entre os desejos presentes em nós assumem muitas formas - a politização é uma maneira de provocar mudanças na ecologia dos desejos. A politização que os feminismos promovem pertence a esse âmbito ecológico: eles tra ta $m$ de a lterar a sprátic as, transfomar ras inc lina ções emoc iona is e problema tiza ra sfonteira s do que é ac eitá vel. Com isso, elespermitem que alguns desejosp reponderantes se transformem. A politiza ção a tua sobre nossa stendências a tomar como fatos da vida certos desejos (nossos e dos outros), c ertas maneiras de manejarnossos desejose certas conseqüências dos desejos. (Politizar o estupro é colocar em questão os desejos que o fazem acontecer; colocar em questão é criar condições para que outros desejos possam acontecer.) Essa concepção ecológica da politização não permite que compreendamos as agendas polític as como agindo em um nível diferente da quele dos desejos; as agendas apenas criam novos elementos que atuam sobre a ecologia de nossas subjetividades. Os feminismos politizam ecologicamente, como Dworkínculo na seção 14 a cima. A politização inserida na ecologia dos desejos pode sempre ser insuficiente; Ritzículo pode prevalecer, mas prevalece se adaptando ao ambiente cria do por Dworkínculo. 
${ }^{47}$ DELEUZE e GUATTARI, 1980.

${ }^{48}$ BRAIDOTT, 1993.
40. Os desejos adquirem seu conteúdo e sua força sobre nóscom referência a o mundo a que eles respondem. A esfera de desejos, apesar de minha no sentido de que posso chegara ela em primeira pessoa, está com asjanelas a bertas a os a mbientes natura is e soc ia is que me envolvem. Deleuze e Guattar $r^{47}$ a presenta ram uma maneira de pensar nos desejos em termos de devires. Trato da ecologia dos meus desejos desde as muitas forças molecula res que me fazem devir diferentes coisas; entre elas enc ontro meu devirfeminista. Trata-se de uma identidade inacabada, talvez inacabável, de contornos tão vagos quanto os meus desejos que conta minam Ritzículo, Dworkínc ulo, entre outros. Talvez os feminismos sejam sempre devires (se bem que talvez convenha entender que também são devires d iferentes em diferentes corporific ações, como a ponta Rosi Braidotti ${ }^{48}$ acerca do devir-mulher). Minha maneira de conceber instintos como inseridos em uma esfera de desejos que se articulam com outras ecologias nasceu desse devir. Esse devir me contaminou de muitas maneiras diferentes; infec tou uma boa parte da produção dosmeus desejos. Poucassão a s espéc ies de desejo que são extintas de uma subjetividade. Os feminismos, cla ramente em mim pelo menos, não provocaram extinções de espécies de desejo. Gosto de pensar, contudo, que eles vão continuar a se propagar como pragas resistentes.

\section{Referências bibliográficas}

ALARCÓN, Norma. "Feminismo chicano: tra s las huella s de "La" mujer na tiva". In: La naturaleza em disputa - Retóricas del cuerpo y el paisaje en America Latina. Buenos Aires: Paidós, 2002. p. 187-202.

ANDALZÚA, Gloria. Borderlands/La Frontera: The New Mestiza. San Francisco: Aunt Lute Books, 1987.

BENSUSAN, Hilan. "Observações sobre a libido colonizada: tentando pensar a o largo do patriarcado". Revista de Estud os Feministas, Floria nópolis, v. 12, n. 1, p. 131-155, 2004a.

- Afinida des eletivas, a finida des compulsórias, pertinênciase impertinências (Sobre um homem branco ensinando Alice Walker, Carolina Maria de Jesus, Toni Morrison e Paulina Chiziane em um departamento de filosofia). Comunicação a presentada no II Colóquio Filosofia e Ficção, UESC, Florianópolis, nov. 2004b. . comunista. Campinas, SP: Komedi, 2005.

BENSUSAN, Hilan; PINEDO, Manuel de. "When My Own Beliefs a re not First-Personal Enough". Teoria, 2006, no prelo. 
BRANDOM, Ro bert. "Voc a bula ries of Pra g ma tism: Synthetizing Na tura lism and Historic ism". In: BRANDOM, R. (ed.). Rorty and his Critics. Oxford: Blackwell, 1999. p. 156-182.

BRAIDOTT, Rosi. Disc ountinuous Becomings: Deleuze on the Becoming-Woman of Philosophy, Journal of the British Society for Phenomenology, v. 24, n. 2, p. 33-55, 1993.

BURERR, J udith. Bodies that Matter. New York: Routledge, 1993.

DAVIDSON, Donald. How is Weakness of the Will Possible? Essays on Actions and Events. Oxford: Clarendon, 1980. . "Truth Rehabilitated". In: BRANDOM, R. (ed.). Rorty and his Critics. Oxford: Blackwell, 2000. p. 65-74.

. "A Coherence Theory of Truth and Knowledge". In: Subjective, Intersubjective, Objective. Oxford: Oxford University Press, 2001a. p. 137-153. "Three Va rieties of Knowledge". In: Subjec tive, Intersubjective, Objective. Oxford: Oxford University Press, 2001b. p. 205-220.

DELEUZE, Giles. Dialogues (com Claire Parnet). Paris: Flammarion, 1977.

DELEUZE, Giles; GUATTARI, Feliz. Mille Plateaux. Pa ris: Minuit, 1980.

ELLER, Cynthia. The Myth of Matriarchal Prehistory. Boston: Beacon Press, 2000.

GIL, J osé. Metamorfoses do corpo. Lisb oa: Relógio D’Água, 1997.

GUATTARI, Félix. Les trois écologies. Pa ris: Galilée, 1989.

HARAWAY, Donna. Symians, Cyborgs and Women: The Reinvention of Nature. New York: Routledge, 1991.

HEGEL, Georg. Phenomenology of Spirit. Oxford: Oxford University Press, 1977; tradução para o inglês da Phänemonologie des Geistes, 1807, por A.V. Miller.

HUME, Da vid. A Treatise of Human Nature. Londres: Dent, 1911; primeira publicação em 1740.

HYDE, Lewis. The Gift - Imagination and the Erotic life of Property. New York: Vintage, 1983.

KAY, J a c kie. Trumpet. Londres: Pic a d or, 1998.

LEWONTIN, Richard. The Triple Helix. Cambridge: Harvard University Press, 2000.

LORDE, Audre. Zami, a New Spelling of my Name. Trumansberg, New York: Crossing 1983.

LOWEN, Alexander. The Language of the Body. New York: Macmillan Publishing Company, 1958.

McDOWELL, John. "Virtue and Reason". In: Mind, Value, \& Reality. Cambridge, Mass.: Harvard University Press, 1998. p. 50-73.

MORAN, Richard. Authority and Estrangement. Princeton: Princeton University Press, 2001.

MORGAN, Elaine. The Desc ent of Woman. London: Souvenir, 1972. 
NOVARO, Marcos; PALERMO, Vic ente. Historia a rgentina: la dicta dura militar 1976/1983. Buenos Aires: Pa idós, 2003.

OZ, Amos. Contra o fanatismo. São Paulo: Ediouro, 2004.

RORTY, Richard. Contingency, Irony, and Solidarity. Cambridge: Cambridge University Press, 1989.

. "Response to Brandom". In: BRANDOM, R. (ed.). Rorty and his Critics. Oxford: Blackwell, 1999.

RUBIN, Gayle. "The Traffic of Women: Notes on the Political Ec onomy of Sex". In: REITER, Rayna R. (ed.). Toward an Anthropology of Women. New York: Monthly Review Press, 1975. p. 157-210.

SANTOS, Gislene Aparecida dos. Mulher negra, homem branco. Rio de Janeiro: Pallas, 2004.

SEGATO, Rita Laura. Las estruturas elementares de la violência: ensayos sobre gênero entre la antropologia, o psicoanalisis y los derechos humanos. Buenos Aires: Universidad Nacional de Quilmes/Prometeo, 2003. v. 1.

VAUG HAM, Geneviève. For-Giving - A Feminist Critique of Exchange. Austin: The Center for the Study of the Gift Ec onomy, 1997.

WALKER, Alice. You Can't Keep a Good Woman Down. San Dieg o: Harvest, 1971.

WITTG ENSTEIN, Ludwig. Philosophic al Investigations. Oxford: Bla c kwell, 1968.

[Recebido em dezembro de 2005 e aceito para publicação em maio de 2006]

\section{Remarks on the Politics of Desire: Trying to Think beyond Compulsory Instincts}

Abstract: This work attempts to artic ula te a feminist and holist ac count of our desires and their relation to nature. I consider desires in relation to our bodies, the environment a round them and how they respond to the forces within our subjectivities, to soc iety around us and to the evolutionary history of our species. I start out considering the separation of the personal and the political and then move on to make some remarks about nature and the three intertwined ecologies described by Guattari. I suggest that we understand the body as a meeting point for those ecologies and, at the same time, as constituting itself a political platform. I then offer a model of how nature constra ins and shape our desire so that no spec ific messa ge is dra wn by our desires from nature. It follows that our desires can be changed as they are not in a ny sense more natural than the rest of our subjec tivity. This change, I claim, is to be thought of in terms of an ecological politic s.

Key Words: Body; Desire; Politics; Pornography; Instinc ts; Ma sc ulinities. 